\title{
IMPACT OF E-MARKETING ON CONSUMER BEHAVIOUR
}

\author{
DR. MONIKA GUPTA ${ }^{1}$, PRIYANSHU SANGAL ${ }^{2}$, SAGAR $^{3}$, RUCHIKA GARG $^{4}$ \\ ${ }^{I}$ Associate Professor, Chandigarh Group of Colleges, Landran, Mohali, Punjab, India \\ ${ }^{2,3,4}$ Students, Chandigarh Business School of Administration, Landran, Mohali, Punjab, India
}

\begin{abstract}
Internet is a powerful medium which connects the customers to the marketers (local as well as global) and provides them a large pool of information. With the enhancement of technology, e-marketing has become an important element for the businesses to fulfill the needs and demands of the consumers. E-marketing is used by the marketers to promote the products and services. Now-a-days, the information is flowing from the television, advertising, magazines, newspaper and internet. Today internet has given many new opportunities for the promotion of the products and services. Earlier methods of the advertisement are now replaced by the new methods like promotion through E-mails, Google Ads etc.

This process of online marketing is very beneficial for the marketers because through this they can reach to maximum customers and can get their feedback easily. This paper examines and focuses on the study of the Emarketing and its impact on the consumer buying behavior also their awareness and acceptance level of the EMarketing. The study also highlighted some of the major challenges which customers face while doing online shopping.
\end{abstract}

KEYWORDS: E-Marketing, Consumer Behavior, Online Shopping, Impact of E-Marketing

Received: Jun 08, 2020; Accepted: Jun 28, 2020; Published: Aug 31, 2020; Paper Id.: IJMPERDJUN2020979

\section{INTRODUCTION}

E-marketing can be considered as marketing of product and services on electronic media such as Internet and World Wide Web to satisfy various demands of the customers. It is based on the effective use of modern internet technologies by the marketers to grow their business. In present world many small as well as large enterprises are using E-marketing to grow their business. When the internet was not present it was not so easy for the marketers to grow and promote their business but now internet has changed the way of marketing completely.

If we talk from the customer's point of view, E-marketing has made the overall shopping experience very easy. As many business are now operating online, so customers can easily get various kinds of the products and services without any kind of hassle. They can easily get the information about various products and services on their mobile phones, computers, laptops, tablets etc. without stepping out of their homes. They can easily compare among different products and services.

Due to E-marketing, we can say that market is just one click away from the customers. If someone is planning his/her business to go online then it is crucial to know about the online customer behavior as the behavior of online customers is different from the behavior of tradition customers. 


\section{Statement of the Problem}

Purchasing behavior of online customer is different from the traditional customers as their preferences change as per the change in technology as well as some other factors. It becomes essential for every business person to study the behavior of online consumer and what are the factors which affects their choices to buy or not to buy something from online market.

\section{OBJECTIVES OF THE STUDY}

The objectives of the present study are as following:

- To study awareness level about e-marketing among the consumers.

- To study the acceptance of e-marketing among consumers.

- To study the impact of e-marketing on purchase decision of consumers.

- To determine the satisfaction level of customers with e-marketing.

\section{LITERATURE REVIEW}

In today's contemporary world, internet has open various communication networks worldwide by connecting with the people throughout the world. The rising trend of internet is manipulating its growth among the users around the globe. The demand of Emarketing has been increased enormously in last 15 years. Organizations are putting a lot of efforts in the promotion of their goods and services through digital platforms. But still most of the people are not aware of E-marketing due to large population in developing and developed countries because they feel unsecure to share their personal information over the internet. That's why companies need to study the impact of consumer buying behavior for E-marketing.

The theory of Reasoned Action (Fishbein, 1980) examines the relationship between attitudes and future intention to participate in these buying behavior. The behavior include: When the customer click on the ads, response to e-mail advertisement, searching of product within the site, product basket, online support service, feedback etc.

According to Cheung et al (Online Consumer Behavior: A Review and agenda for future Research, 2003), a base model called Model of Intention, Adoption and Communication (MIAC) for the development of an online consumer behavior framework. This model predicts that behavior is governed by intention. Satisfied consumers are most likely to continue hence adoption and continuance are connected to each other through several mediating and moderating factors such as trust and satisfaction.

There are many factors which affect the behavior of consumer, some of those are: individual characteristics, online merchants and middle as well as intermediate characteristics.

Analyzing the other side of issue, different picture has been created, thus culture can also be seen as one of the key factors in both e-marketing adoption and performance. The first aspect when implementing e-marketing is the availability of a friendly commodity and atmosphere. Without the culture of support, technology may not be able to replace the relationship between marketer and customer. The strong human orientation may make the self-service somewhat unattractive for many e-marketing based activities. On the other hand, there are many aspects of culture which can affect the adoption enterprises for e-marketing. These factors include: people's attitude, confidence, protection, lack of social acceptance, acceptance of customer and e-marketing environment. 
Patricia Sorce, Victor Peroti and Stanley Widrick (2005) opine that an age difference explains more variance than additional factors in online shopping. Older generations shows more brand loyalty as they make less comparison between products and make immediate purchases as and when they search than younger generation.

\section{RESEARCH METHODOLOGY}

\section{Primary Data}

This research is done through collection of data by with the help of questionnaires. We prepared a questionnaire and ask the respondents to fairly answer all the questions mentioned in that.

\section{Secondary Data}

To develop the theoretical portion of this research we collected the secondary data from ebooks, books and journals.

\section{Sample Size}

The sample size is 103 respondent's opinion randomly so that we can collect the information regarding both types of customers which shop online as well as which prefer traditional mode of shopping.

\section{Data Analysis}

We've analyzed all the responses which we get from our respondents. Summary of these responses is as following:

Table 1: Demographic Features

\begin{tabular}{|c|c|c|c|}
\hline Particulars & Category & No. of Respondents & Percentage of Respondents \\
\hline \multirow{2}{*}{ Gender } & Female & 50 & 48.54 \\
\hline & Male & 53 & 51.46 \\
\hline \multirow{2}{*}{ Area } & Rural & 13 & 12.62 \\
\hline & Urban & 90 & 87.38 \\
\hline \multirow{6}{*}{ Age Group } & 12 to 18 & 50 & 48.54 \\
\hline & 18 to 25 & 32 & 31.07 \\
\hline & 25 to 35 & 6 & 5.83 \\
\hline & 35 to 45 & 5 & 4.85 \\
\hline & 45 to 60 & 8 & 7.77 \\
\hline & 60 above & 2 & 1.94 \\
\hline \multirow{5}{*}{ Profession } & Student & 67 & 65.05 \\
\hline & Service & 21 & 20.39 \\
\hline & Businessmen & 4 & 3.88 \\
\hline & Housewife & 8 & 7.77 \\
\hline & Retired & 3 & 2.91 \\
\hline
\end{tabular}

Looking at the demographic features, we got maximum responses from the urban area which is approx. 88 percent, also they belong to age group 12 years to 25 years i.e. young generation and most of them are students and some are engaged in public and private services.

Table 2: Awareness about E-Marketing

\begin{tabular}{|l|l|c|c|}
\hline \multicolumn{1}{|c|}{ Particulars } & Category & No of Respondents & Percentage of Respondents \\
\hline \multirow{2}{*}{ Awareness about E-Marketing } & Yes & 100 & 97.09 \\
\cline { 2 - 4 } & No & 3 & 2.91 \\
\hline \multirow{3}{*}{ Information Source for E-Marketing } & Social Media & 67 & 65.05 \\
\cline { 2 - 4 } & TV Ads & 30 & 29.13 \\
\cline { 2 - 4 } & Newspaper & 6 & 5.83 \\
\hline
\end{tabular}


Our $97 \%$ respondents are aware about E-Marketing and its practices and there are about $3 \%$ respondents who are not aware about E-Marketing. Which indicates that maximum number of people know about E-marketing. Most of the people get to know about the E-marketing and online shopping sites from Social Media and TV advertisement.

Table 3: Preferred Mode of Shopping

\begin{tabular}{|c|c|c|}
\hline Category & No. of Respondents & Percentage of Respondents \\
\hline Online Shopping & 52 & 50.49 \\
\hline Offline Shopping & 51 & 49.51 \\
\hline
\end{tabular}

If we look at the preferred shopping mode of our respondents, it is a tie which means $50 \%$ respondents prefer to shop online while remaining $50 \%$ prefer to shop via traditional mode of shopping i.e. visiting stores.

Table 4: Products Preferred for Online Shopping

\begin{tabular}{|l|c|c|}
\hline \multicolumn{1}{|c|}{ Category } & No of Respondents & Percentage of Respondents \\
\hline Clothes \& Footwears & 46 & 44.67 \\
\hline Stationary & 1 & 0.97 \\
\hline Jewellery & 7 & 6.8 \\
\hline Grocery & 2 & 1.94 \\
\hline Electronics & 29 & 28.16 \\
\hline Others & 18 & 17.47 \\
\hline
\end{tabular}

Maximum number of respondents approx. $45 \%$ like to purchase clothes and footwear from online shopping sites while there are $29 \%$ respondents who buy electronic appliances. Shopping preference for stationary, jewellery and grocery items is comparatively low.

Table 5: Reasons to Shop Online

\begin{tabular}{|l|c|c|}
\hline \multicolumn{1}{|c|}{ Category } & No of Respondents & Percentage of Respondents \\
\hline Variety of Products & 31 & 30.1 \\
\hline Attractive Price & 25 & 24.27 \\
\hline Availability of Rare Products & 32 & 31.07 \\
\hline Heavy Discounts & 15 & 14.56 \\
\hline Others & 18 & 17.47 \\
\hline
\end{tabular}

Maximum number of our respondents like to shop online because there is availability of rare products on shopping sites which they do not get in offline shopping. Other major reason to shop online is the variety of products. Online shopping sites have huge variety of products in terms of colors, size, shape, quality, price range etc. Also they provide these products at attractive prices so the customers like to shop online.

Table 6: Issues Faced while Shopping Online

\begin{tabular}{|l|c|c|}
\hline \multicolumn{1}{|c|}{ Category } & No of Respondents & Percentage of Respondents \\
\hline Non User-Friendly App/Website & 23 & 22.33 \\
\hline Payment related issues & 23 & 22.33 \\
\hline Misleading Price & 29 & 28.16 \\
\hline Inadequate Return Policy & 28 & 27.18 \\
\hline
\end{tabular}

There are many issues which act as an obstacle for the customers to shop online. One of the major issue which online customers face is misleading price of the products. Frequent changes in the prices of products can lose the trust of their customers. Other reason is that the website or app for online shopping site is not user friendly so they get confused 
when they try to make any online purchase. Also some customers face payment related issue sometimes there payment is not successful or sometimes their transaction get cancelled which makes customers irritated and it leaves a negative impression on the customers for online shopping.

Table 7: Consideration for Reviews while Shopping Online

\begin{tabular}{|l|c|c|}
\hline Category & No of Respondents & Percentage of Respondents \\
\hline Always & 51 & 49.51 \\
\hline Sometimes & 43 & 41.75 \\
\hline Never & 9 & 8.74 \\
\hline
\end{tabular}

Reviews are very important to consider for every customer. Approx. 90\% of customers look for the reviews before purchasing anything online.

Table 8: Satisfaction Level for E-Marketing

\begin{tabular}{|l|l|c|c|}
\hline \multicolumn{1}{|c|}{ Particulars } & \multicolumn{1}{|c|}{ Category } & $\begin{array}{c}\text { No of } \\
\text { Respondents }\end{array}$ & $\begin{array}{c}\text { Percentage of } \\
\text { Respondents }\end{array}$ \\
\hline \multirow{3}{*}{$\begin{array}{l}\text { Satisfied with quality of products } \\
\text { purchased online }\end{array}$} & Always & 10 & 9.71 \\
\cline { 2 - 4 } & Most of the time & 42 & 40.78 \\
\cline { 2 - 4 } & Sometimes & 43 & 41.75 \\
\cline { 2 - 4 } Make Repeat Online Purchase & Never & 8 & 7.77 \\
\hline \multirow{3}{*}{$\begin{array}{l}\text { Satisfied with overall online } \\
\text { shopping experience }\end{array}$} & Yes & 78 & 24.27 \\
\cline { 2 - 4 } & No & 54 & 52.45 \\
\cline { 2 - 4 } & Yes & 8 & 7.77 \\
\cline { 2 - 4 } & No & 41 & 39.81 \\
\cline { 2 - 4 } & Upto Some & & \\
\hline
\end{tabular}

As per the analysis around $90 \%$ of the customers are satisfied with the quality of products purchased online and $76 \%$ customers like to make repeat purchase from online shopping sites. Around $90 \%$ of customers are satisfied from the overall online shopping experience. So it is essential that the quality should be good of all the products as it is the primary concern for every customer and it increases their chance to make repeat purchase.

Table 9: Effectiveness of E-Marketing over Traditional Marketing

\begin{tabular}{|c|c|c|c|}
\hline Particulars & Category & $\begin{array}{c}\text { No of } \\
\text { Respondents }\end{array}$ & $\begin{array}{l}\text { Percentage of } \\
\text { Respondents }\end{array}$ \\
\hline \multirow{4}{*}{$\begin{array}{l}\text { E-marketing has made shopping } \\
\text { experience very easy }\end{array}$} & Strongly agree & 21 & 20.39 \\
\hline & Agree & 70 & 67.96 \\
\hline & Disagree & 9 & 8.74 \\
\hline & Agree & 3 & 2.91 \\
\hline \multirow{3}{*}{$\begin{array}{l}\text { Influenced positively by online } \\
\text { advertisements }\end{array}$} & Yes & 49 & 47.57 \\
\hline & No & 23 & 22.33 \\
\hline & Upto Some Extent & 31 & 30.1 \\
\hline \multirow{3}{*}{$\begin{array}{l}\text { E-marketing is effective over } \\
\text { traditional marketing practices }\end{array}$} & Effective & 44 & 42.72 \\
\hline & $\begin{array}{l}\text { Effective upto Some } \\
\text { Extent }\end{array}$ & 42 & 40.78 \\
\hline & Not Effective & 17 & 16.5 \\
\hline
\end{tabular}

About $88 \%$ customers accept that E-Marketing and online shopping has made the shopping experience very easy as they do not need to go outside for shopping and they get everything at their doorstep. Regular promotion increases chance for the customers to make online shopping as $48 \%$ customers agree that they have been influenced positively by the 
advertisement on social media sites and other modes of advertisement about online shopping sites and 30\% customers agree that they have been influenced by online ads for shopping online upto some extent. Around $84 \%$ customers are agree that E-Marketing is effective over the traditional marketing practices.

\section{SUGGESTIONS AND RECOMMENDATIONS}

- Online marketers should have a proper feedback system so that they can deliver the maximum level of satisfaction to their customers.

- Trust is the most essential element in online shopping. E-marketers should try to build a trust in the eyes of their customers. It can be achieved by providing them quality products and services at fair prices. Frequent price changes leaves negative impact on the customers buying behavior.

- Technology should be properly used to promote the products and services with the help of e-marketing tools. Promotion is essential for online marketers as it increases chance for the customers to shop online.

- There should be a transparent service to the customer before as well as after the purchase. If they are satisfied with overall shopping experience then they will surely make repeat purchase.

- There should be no issue of price mismatch otherwise the customer will not make a repeat purchase due to lack of trust.

\section{CONCLUSIONS}

E-marketing is shifting rapidly in the way people do business worldwide. Sales over the web have increased dramatically in the business-to-consumer segment over the last few years. Customers are getting used to the new shopping channel, not just those from well-developed countries but also those from developing countries.

E-marketing is gaining popularity among people especially the younger generation but e-marketing will have to cover a longer distance in today's scenario to become equally popular among all age groups. People hesitate to use eservices because of security concerns, lack of physical approach to the product being offered, delays in the delivery of the product, along with price \& quality concerns. In fact, people are more resistant to change and are not readily adaptable to new technologies.68 per cent of respondents find shopping from the shop faster, more convenient \& better than online shopping. Finding above clearly supports our conclusion that people are bound by tradition and have doubts in mind when it comes to online shopping / product purchasing.

People have a dubious attitude towards product \& services e-marketing mainly due to security concerns regarding the privacy of personal information. The protection of personal information should be given priority by the organizations involved in the goods \& services marketing online. Another major concern among people is the authenticity of the online offered products \& services. Online trading companies should focus on building their brand awareness among people, so that trustworthy relationships between producers and consumers can be developed. In the long run, delivery on time of items purchased via online shopping would prove very beneficial.Major price reductions can be provided to consumers, since comparatively no / lesser intermediaries are involved with e-marketing.Currency fluctuation should be treated very cautiously, and measures should be taken by both government and businesses to reduce currency fluctuation. 
Promotional schemes to promote the e-marketing business should be launched. Web-products \& services advertising is one of the major issues where companies fail to attract the attention of potential consumers. Companies should focus on providing informative advertising that would include product information along with additional products and services that best suit people's needs. Such frequency of advertisements should be high to position the products $\&$ brands in the mindset of consumers. In a nut shell we can conclude that emarketing has a potential to grow, only proper boosting needs to be done both at producer and consumer level apart from government efforts.

\section{FUTURE SCOPE OF THE STUDY}

- $\quad$ There should be conduct of surveys and seminars to aware the people from villages about the E marketing.

- The E marketing must provide more easy websites so that anyone can use it easily without facing any problems.

- $\quad$ There should be better quality products with no misleading of the prices.

- There is great freedom in the Electronic payments of paying their taxes, licenses etc.

- As a result; information is conveyed easily and also development cost is reduced.

- E marketing is a long term process and it can also help in the reduction of the branches of the shops and also reduced the rental problems.

\section{REFERENCES}

1. Hooda, Sanjay, and Aggarwal, Sandeep, “Consumer Behaviour towards E-Marketing: A Study of Jaipur Consumers” Vol-III, Issue 2(2), April 2012 [107].

2. Sathya, p. "A Study on Digital Marketing and its Impact” Volume 6, Issue 2, February 2017.

3. Malik, Reena, “An Empirical Study of Digital Marketing and its Elements” Volume 3, Issue 8, 2017 IJSRT.

4. Wadhawan, Seema, Gupta, Sweety, and Dua, Shikha, "An Empirical Study of the Factors influencing the effectiveness of Online Advertisement” IOSR Journal of Computer Engineering (IOSR-JCE) e-ISSN: 2278-0661, p-ISSN: 2278-8727. 
